\title{
In Memoriam: Judith Stein
}

\author{
Joshua B. Freeman \\ Queens College, City University of New York
}

Judith Stein, a long-time member of the $I L W C H$ editorial board, died on May 8 , 2017 after a long battle with cancer. Distinguished Professor of History at City College and the Graduate Center of the City University of New York, Stein was one of the leading historians of the twentieth-century United States, especially of African American politics, labor, and political economy. She was widely admired for her fierce integrity and critical spirit as well as for her historiographical contributions.

Stein joined the ILWCH editorial board in 1993, when it was still heavily weighted toward Europeanists, reflecting the origin of the journal as a newsletter covering European labor history. She immediately became an influential force at the journal, writing book reviews and contributing to a series of roundtable and scholarly controversy features. She was the prime force behind the Fall 2001 journal section on "Whiteness and the Historians' Imagination," featuring an article of that title by Eric Arnesen and responses by leading scholars of labor and race, one of the first critical assessments of the idea of "whiteness" and to this day one of the most widely read set of articles in the history of ILWCH. At editorial board meetings, Stein pushed against faddishness and rhetorical flourish, demanding clarity and scholarship grounded in the sources. Many times a discussion of a proposed article or issue would seem to be winding down when Judy would say, "I don't understand what this means," pointing out a facile formulation or unsupported claim that forced her colleagues to reconsider.

Throughout her career, Stein believed in the centrality of class as a way of understanding modern US history. In her first piece for $I L W C H$, published in 1994, a response to an article by outgoing coeditor Ira Katznelson about the future of labor history, she defended the utility of studying class and criticized then fashionable historiographic trends in her usual sharp fashion. "Although capitalist development does not produce inevitable identities, policies or results," she wrote, "changing class relations have typically launched the most important social changes and movements in modern society." Though acutely sensitive to issues of race in her own work-she began as an African Americanist-she took to task historians who disconnected them from material circumstances. Making "linguistic analysis ... a surrogate for historical research," Stein said, led to constructing "iron cages out of gender and race."1 Long before the current explosion of scholarship on the history of capitalism, Stein took labor historians to task for ignoring the larger context of workingclass life. "The problem of social history may not be its alleged privileging of the working-class," she wrote in $I L W C H$ in 2000 , "but its disinterest in the 
history of capitalism." "The virtue of class as an analytic category is that it begins with the notion of accumulation as a driving force of change." 2

In her own work, Stein showed how social outcomes came from complex interactions between worker activity, state policy, and global trends. Her first book, The World of Marcus Garvey: Race and Class in Modern Society (1986), situated Garvey and Garveyism in a global context, then a very unusual approach for an American historian, while elucidating the class tensions within the movement. Running Steel, Running America: Race, Economic Policy and the Decline of Liberalism (Chapel Hill, 1998) provided one of the first and still best efforts to look at the relationship between struggles for racial justice on the job and the political economy of industry (until then usually treated as entirely separate subjects). In it, she charted the long, difficult fight against racial discrimination in the steel industry, juxtaposing it with an analysis of government policies that undermined the industry itself. Tragically, just as black workers began winning something approaching equal opportunity, the steel industry imploded, leading to massive job losses by white and black workers. Stein put much of the blame on the turn by liberalism and the Democratic Party away from economic policies that served working people, sacrificing them to trade and other policies meant to boost allies in the global anticommunist struggle. She expanded on this theme in Pivotal Decade: How the United States Traded Factories for Finance in the Seventies (New Haven and London, 2011), showing how Reaganism filled the vacuum created by the failure of Democratic liberals to develop an effective economic policy during the global recession of the 1970s. Stein was critical of the liberal wing of the Democratic Party, influenced by the New Left, for abandoning its blue-collar base while their old-line opponents, like AFL-CIO president George Meany (rarely a favorite of historians) continued to advocate for an industrial policy that would preserve American manufacturing.

For her students and colleagues, Judith Stein served as a model of a committed but clear-eyed left intellectual, unwilling to put up with fatuous cant from any direction. She took history seriously; as her ILWCH colleague and friend Geoffrey Field remembered, "She didn't duck, sweeten, soften or prevaricate - things were too important for that." But her intellectual disagreements were never personal. A vibrant presence, a person of great intellectual and personal courage, and a scholar who demonstrated over and over again the importance of labor and working-class history to understanding the past and the present, she will be greatly missed.

\section{NOTES}

1. Judith Stein, "Engaged History," International Labor and Working-Class History 46 (1994): 81-85.

2. Judith Stein, "Where's the Beef," International Labor and Working-Class History 57 (2000): 40-47. 